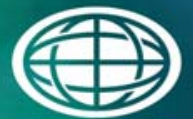

Savannah River

National Laboratory "m

OPERATED BY SAVANNAH RIVER NUCLEAR SOLUTIONS

\title{
Discoloration of the Wetted Surface in the 6.1D Dissolver
}

T. S. Rudisill, J. I. Mickalonis, and K. P. Crapse

December 2013

SRNL-STI-2013-00717 


\section{DISCLAIMER}

This work was prepared under an agreement with and funded by the U.S. Government. Neither the U.S. Government or its employees, nor any of its contractors, subcontractors or their employees, makes any express or implied:

1. warranty or assumes any legal liability for the accuracy, completeness, or for the use or results of such use of any information, product, or process disclosed; or

2. representation that such use or results of such use would not infringe privately owned rights; or

3. endorsement or recommendation of any specifically identified commercial product, process, or service.

Any views and opinions of authors expressed in this work do not necessarily state or reflect those of the United States Government, or its contractors, or subcontractors.

\section{Printed in the United States of America \\ Prepared for U.S. Department of Energy}


Keywords: H-Canyon, Dissolver, Discoloration, Corrosion

Retention: Permanent

\section{Discoloration of the Wetted Surface in the 6.1D Dissolver}

T. S. Rudisill

J. I. Mickalonis

K. P. Crapse

December 2013

Prepared for the U.S. Department of Energy under 


\section{REVIEWS AND APPROVALS}

\section{AUTHORS:}

T. S. Rudisill, Separations and Actinide Science Programs

Date

J. I. Mickalonis, Material Performance and Corrosion Technology

Date

K. P. Crapse, Separations and Actinide Science Programs

Date

TECHNICAL REVIEW:

M. L. Crowder, Separations and Actinide Science Programs, Reviewed per E7 2.60

Date

W. H. Clifton, Jr., H-Canyon Engineering

Date

APPROVAL:

T. B. Brown, Manager

Date

Separations and Actinide Science Programs

K. E. Zeigler, Manager

Date

Material Performance and Corrosion Technology

S.L. Marra, Manager

Date

Environmental \& Chemical Process Technology Research Programs

K. J. Usher, Manager

Date

$\mathrm{H}$-Canyon Engineering 


\section{EXECUTIVE SUMMARY}

During a camera inspection of a failed coil in the 6.1D dissolver, an orange discoloration was observed on a portion of the dissolver wall and coils. At the request of $\mathrm{H}$-Canyon Engineering, the inspection video of the dissolver was reviewed by SRNL to assess if the observed condition (a non-uniform, orange-colored substance on internal surfaces) was a result of corrosion. Although the dissolver vessel and coil corrode during dissolution operations, the high acid conditions are not consistent with the formation of ferrous oxides (i.e., orange/rust-colored corrosion products). In a subsequent investigation, SRNL performed dissolution experiments to determine if residues from the nylon bags used for Pu containment could have generated the orange discoloration following dissolution. When small pieces of a nylon bag were placed in boiling $8 \mathrm{M}$ nitric acid solutions containing other components representative of the H-Canyon process, complete dissolution occurred almost immediately. No residues were obtained even when a nylon mass to volume ratio greater than 100 times the 6.1D dissolver value was used. Degradation products from the dissolution of nylon bags are not responsible for the discoloration observed in the dissolver. 


\section{TABLE OF CONTENTS}

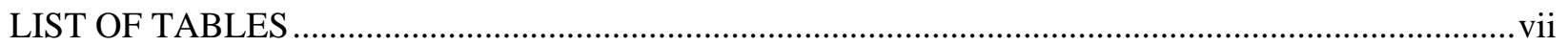

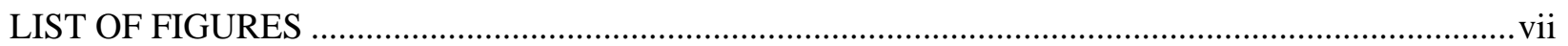

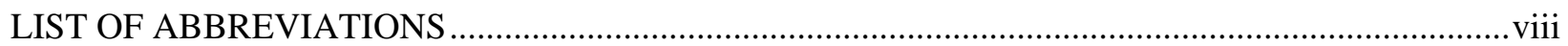

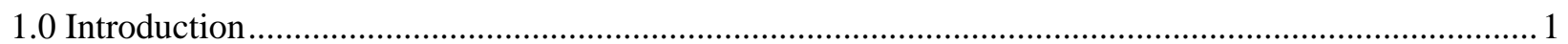

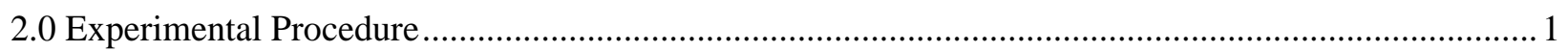

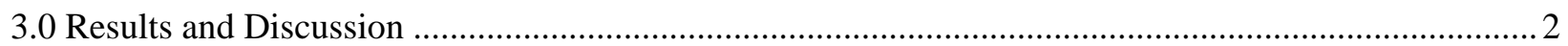

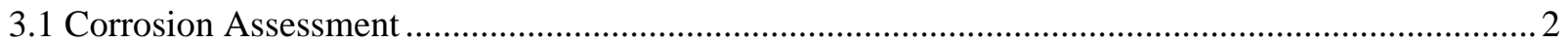

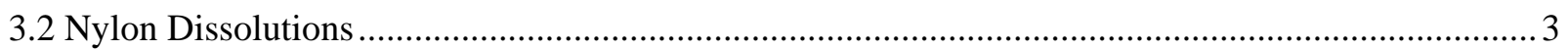

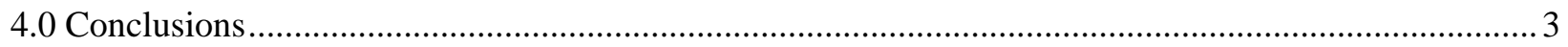

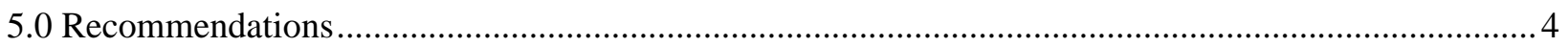

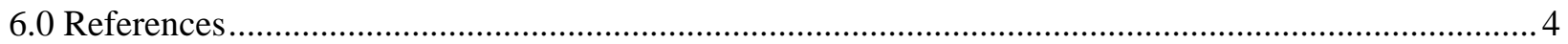




\section{LIST OF TABLES}

Table 2-1. Conditions for Nylon Dissolution Experiments . .2

\section{LIST OF FIGURES}

Figure 3-1. Dissolution of Nylon Bag in 8 M Nitric Acid Solution ....................................................... 3 


\section{LIST OF ABBREVIATIONS}

$\begin{array}{ll}\text { AFS-2 } & \text { Alternate Feed Source } 2 \\ \text { SRNL } & \text { Savannah River National Laboratory } \\ \text { mpy } & \text { mils per year }\end{array}$




\subsection{Introduction}

During a camera inspection of the failed 6.1D dissolver lower coils, an orange discoloration on a fraction of the dissolver coils and wall next to the east canyon wall was observed. The locations of the discoloration appeared random in nature and darker on the top of the upper coils. The nozzles in this section of the dissolver provide utility services (e.g., cooling water and steam outlet and sparge/purge air) and transfer jets from the dissolver. No chemical additions occur in this area of the dissolver [1]. The orange discoloration is not believed to be related to the corrosion of the dissolver. The dissolution of Pu metal for the AFS-2 program is being performed using high concentrations of nitric acid and fluoride which exacerbate the corrosion rate [2]; however, the high acid conditions are not consistent with the formation of ferrous oxides (i.e., orange/rust-colored corrosion products). The corrosion evaluation performed in response to the discovery of the discoloration is discussed in section 3.1 [3].

Based on the visual inspection of the dissolver coils and wall and the corrosion evaluation, $\mathrm{H}$-Canyon Engineering concluded that the discoloration appeared unrelated to the dissolver operation and speculated that the discoloration occurred during fabrication prior to the dissolver being put into service [1]. To strengthen this assumption, SRNL evaluated the potential for degradation products from the dissolvable nylon bags (used to transfer the $\mathrm{Pu}$ metal to the dissolver charging bundles) to generate an orange-colored residue which could accumulate on surfaces in the dissolver. Two experiments were performed in which pieces of a nylon bag were added to a simulated $\mathrm{Pu}$ metal dissolving solution. A description of the experiments and a discussion of the results are provided in following sections.

\subsection{Experimental Procedure}

SRNL was recently tasked with modifying the dissolution flowsheet used in H-Canyon to prepare $\mathrm{Pu}$ metal for the AFS-2 program. The objectives of the experimental work were to find dissolution conditions that adequately dissolve the Pu metal, reduce the corrosion of the dissolver, and eliminate or significantly reduce the oxidation of $\mathrm{Pu}(\mathrm{IV})$ to $\mathrm{Pu}(\mathrm{VI})$ due to the presence of $\mathrm{Cr}(\mathrm{VI})$ in the solution [4-5]. In these experiments, concentrations of $\mathrm{Pu}, \mathrm{Fe}, \mathrm{Ni}$, and $\mathrm{Cr}$ representative of the concentrations following a Pu metal dissolution were prepared in a 7-8 $\mathrm{M}$ nitric acid solution containing $0.1 \mathrm{M} \mathrm{KF}$ and $1.6 \mathrm{~g} / \mathrm{L} \mathrm{B}$. The solutions were heated (at 95 to $112{ }^{\circ} \mathrm{C}$ ) for approximately 40 to $240 \mathrm{~h}$. During the heating cycle the Pu(VI) concentration was periodically measured by UV-visible spectroscopy. Following two of the simulated dissolution experiments, a piece of a nylon bag was added to the reaction vessel and heated until the nylon

piece dissolved. The compositions of the solution used in each experiment and the masses of nylon are provided in Table 2-1. Approximately $100 \mathrm{~mL}$ of solution were heated to boiling $\left(112^{\circ} \mathrm{C}\right)$ prior to the addition of each piece of nylon. 
SRNL-STI-2013-00717

Revision 0

Table 2-1. Conditions for Nylon Dissolution Experiments

\begin{tabular}{|l|c|c|}
\hline Component & Test 1 & Test 2 \\
\hline & & \\
\hline $\mathrm{HNO}_{3}(\mathrm{M})$ & 8 & 8 \\
\hline $\mathrm{KF}(\mathrm{M})$ & 0.1 & 0.1 \\
\hline $\mathrm{Pu}(\mathrm{g} / \mathrm{L})$ & 3.5 & 3.5 \\
\hline $\mathrm{B}(\mathrm{g} / \mathrm{L})$ & 1.6 & 1.6 \\
\hline $\mathrm{Fe}(\mathrm{g} / \mathrm{L})$ & 3.7 & 3.7 \\
\hline $\mathrm{Ni}(\mathrm{g} / \mathrm{L})$ & 0.4 & 0.4 \\
\hline $\mathrm{Cr}(\mathrm{g} / \mathrm{L})$ & 0.6 & 0.6 \\
\hline & & \\
\hline Nylon Mass $(\mathrm{g})$ & 1.4 & 0.013 \\
\hline Temperature $\left({ }^{\circ} \mathrm{C}\right)$ & 112 & 112 \\
\hline Volume $(\mathrm{mL})$ & 100 & 100 \\
\hline
\end{tabular}

\subsection{Results and Discussion}

\subsection{Corrosion Assessment}

A section of the internal surfaces of the 6.1D dissolver including the vessel sidewall, coils and coil supports had a non-uniform orange discoloration. This discoloration was primarily on one side near nozzles used for the steam and cooling water outlet and sparge/purge air. The discoloration was nearly diagonally across from the cold chemical feeds where nitric acid and KF are added. The discoloration was heavier on the top of coils as well as on the upper coils and gave the appearance on certain surfaces to be gelatinous. On some short sections of pipe the discoloration appeared to end along a fairly straight line that was parallel to the pipe length or a solution line. The discoloration was not found on dissolver inserts.

In the concentrated nitric acid/KF solution used for $\mathrm{Pu}$ dissolution, the corrosion products of stainless steel are soluble and would not be expected to precipitate from solution. During recent testing in support of dissolutions in $10 \mathrm{M}$ nitric acid with up to $0.2 \mathrm{M}$ fluoride, the test coupons were free of any orange/rust-colored substances [6]. After recent H-Canyon dissolutions that utilized $10 \mathrm{M}$ nitric acid with $0.1 \mathrm{M}$ fluoride the $\mathrm{Fe} / \mathrm{Cr} / \mathrm{Ni} / \mathrm{Mn}$ ratios were evaluated from chemical analyses of the dissolver solution. These ratios are consistent with the nominal composition of 304L stainless steel, the material of construction of the H-Canyon dissolver. Therefore, ferrous/ferric corrosion products (i.e. rust) do not appear to be dropping out of the dissolver solution, although this measurement is only a rough estimate. Additionally, corrosion rates were calculated from the solution analysis (140 to 300 mpy depending on time of dissolution) and are consistent with the data from the laboratory testing (120 to 300 mpy depending on surface area of exposure). The 6.1D dissolver does not appear to be experiencing accelerated corrosion.

The processing steps (i.e., order of chemical additions) were reviewed to evaluate whether changes in $\mathrm{pH}$ or solution concentration could be contributing factors. The chemical additions to the dissolver prior to processing were: $10 \mathrm{M}$ nitric acid containing $\mathrm{B}, \mathrm{KF}$ solution and process water to flush the piping from the head tank to the dissolver. The dissolver prior to processing would only see acidic conditions and any corrosion products which may have formed would be expected to be soluble in the acidic solution. After dissolution and transfer, no other chemical additions are made to the dissolver until the next dissolution so a thin layer of acidic solution would cover the dissolver surfaces. During the laboratory corrosion tests with vapor exposed 
coupons a thin acidic film covers these coupons and orange/rust-colored corrosion products were not observed [6].

\subsection{Nylon Dissolutions}

In the initial nylon dissolution experiment a $1.4 \mathrm{~g}$ sample was added to the dissolving vessel. Once in the solution, the nylon dissolved immediately generating a small amount of brown $\mathrm{NO}_{2}$ gas. Inspection of the vessel and solution following cooling revealed no orange-colored residue. The small amount of solids present in the vessel was attributed to the corrosion of the glass vessel due to the high concentration of fluoride in the solution. Complete dissolution of the nylon is consistent with the results from previous work performed to evaluate the use of nylon bags in canyon dissolvers [7-8]. In one study, a sample of the nylon material was dissolved in concentrated nitric acid and the solution analyzed by gas chromatography. The experiment showed that the nylon readily dissolved producing a variety of decomposition products [7]. The incomplete destruction of nylon has not been a problem during its use in either $\mathrm{F}$ or H-Canyon dissolvers due to the small amount of bag material that was added to a dissolver.

The ratio of the nylon to the volume of solution used in the initial experiment was approximately $14 \mathrm{~g}$ of nylon per liter of solution. This value is greater than one hundred times the ratio used in the 6.1D dissolver for a Pu metal dissolution. The approximate mass of nylon bag used to contain one can of $\mathrm{Pu}$ metal is $77 \mathrm{~g}$. Ten cans of Pu per batch are charged to the 6.1D dissolver which contains $6000 \mathrm{~L}$ of solution; therefore, the ratio used in dissolver is $0.13 \mathrm{~g} / \mathrm{L}$. The second nylon dissolution experiment was performed using this ratio. Figure 1 shows photographs of the vessel before and after the dissolution of the nylon material.

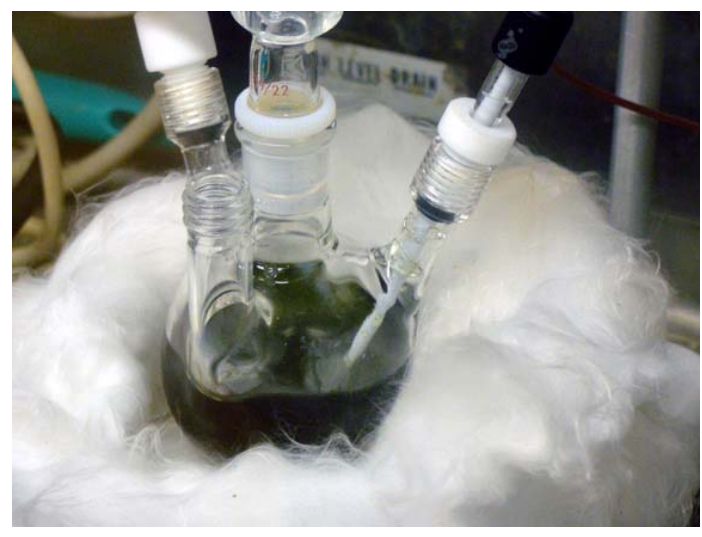

Before

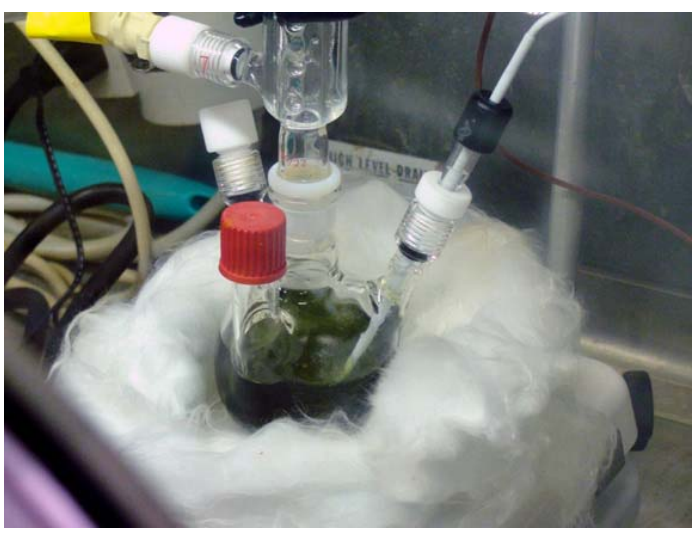

After

Figure 3-1. Dissolution of Nylon Bag in 8 M Nitric Acid Solution

There were no discernible differences in the appearance of the solution when compared before or after the dissolution of the nylon. Complete dissolution of the small piece was achieved and no residues attributed to the nylon were observed.

\subsection{Conclusions}

Two potential sources of the orange discoloration on the 6.1D dissolver wall and coils were evaluated. Based on a review of the dissolver inspection video and previous corrosion studies, SRNL concluded that the discoloration was not due to the buildup of corrosion products on the metal surfaces. In the concentrated nitric acid/KF solution used for Pu dissolution, the corrosion products of stainless steel are soluble and would not be expected to precipitate from solution. 
In a subsequent investigation, dissolution experiments were performed to determine if residues from the nylon bags used for Pu containment could have generated the orange discoloration. When small pieces of a nylon bag were placed in a simulated dissolving solution, complete dissolution of the nylon was obtained even when a nylon mass to volume ratio greater than 100 times the 6.1D dissolver value was used. Degradation products from the dissolution of nylon bags are not responsible for the discoloration observed in the dissolver.

\subsection{Recommendations}

Three recommendations are provided for a more complete assessment of the origination of the discoloration on the 6.1D dissolver wall and coils.

- Obtain a sample of the orange-colored material for chemical analysis and the identification of the principal constituents.

- Inspect the 6.4D vessel to determine if the orange discoloration is a unique occurrence in the $6.1 \mathrm{D}$ vessel.

- Monitor changes in the discoloration following additional dissolution to determine if the quantity of material is increasing or stagnant.

An additional recommendation for minimizing the uncertainty of dissolver condition in the future is to inspect all new dissolver vessels prior to installation to document the initial condition.

\subsection{References}

1. W. H. Clifton, Jr. and J. L. Bodkin to M. J. Lewczyk, 6.1D Coil Inspection, SRNS-H81002013-00038, Rev 1, Savannah River Nuclear Solutions, Aiken, SC 29808, July 18, 2013.

2. T. S. Rudisill and R. A. Pierce, Dissolution of Plutonium Metal in 8-10 M Nitric Acid, SRNL-STI-2012-00043, Rev. 1, Savannah River National Laboratory, Aiken, SC, July 2012.

3. J. L. Mickalonis to W. H. Clifton, Jr., RE: Inspection of 6.1D Dissolver - Corrosion Assessment of Orange Discoloration, SRNL-L4400-2013-00013, Rev. 0, Savannah River National Laboratory, Aiken, SC, July 18, 2013.

4. W. H. Clifton, AFS-2 Flowsheet Modification, NMMD-HTS-2013-3234, Savannah River Nuclear Solutions, Aiken, SC, April 15, 2013.

5. T. S. Rudisill and K. P. Crapse, Task Technical and Quality Assurance Plan for AFS-2 Flowsheet Modification: The Effect of Nitric Acid Concentration and Temperature on the Oxidation of Cr(III) to Cr(VI), SRNL-RP-2013-00315, Rev. 1, Savannah River National Laboratory, Aiken, SC, August 2013.

6. J. I. Mickalonis to W. H. Clifton, Corrosion Testing in Support of H-Canyon Dissolver and Evaporators, SRNL-L4400-2012-00002, Savannah River National Laboratory, Aiken, SC, July 19, 2012

7. J. E. Laurinat, Testing of Nylon Bag Material, WSRC-TR-97-0211, Rev. 0, Westinghouse Savannah River Company, Aiken, SC, July 15, 1997.

8. R. A. Pierce to W. H. Clifton, Dissolution of LLNL Can and Nylon Sleeve Materials, SRNLL3000-2008-00030, Rev. 2, Savannah River National Laboratory, Aiken, SC, February 10, 2009. 


\section{Distribution:}

S. L. Marra, 773-A

T. B. Brown, 773-A

D. H. McGuire, 999-W

S. D. Fink, 773-A

C. C. Herman, 773-A

E. N. Hoffman, 999-W

F. M. Pennebaker, 773-42A

W. R. Wilmarth, 773-A

K. E. Zeigler, 773-41A

J. I. Mickalonis, 773-A

M. L. Crowder, 773-A

W. E. Harris, 704-2H

J. B. Schaade, 704-2H

P. B. Andrews, 704-2H

K. P. Burrows, 704-2H

S. L. Hudlow, 221-H

K. J. Usher, 704-2H

W. H. Clifton Jr., 704-2H

M. J. Lewczyk, 221-H

P. R. Jackson, 703-46A

Records Administration (EDWS) 